\title{
Structures, bonding and reactivity of iron and manganese high-valent metal-oxo complexes: A computational investigation
}

\author{
BHAWANA PANDEY, AZAJ ANSARI, NIDHI VYAS and GOPALAN RAJARAMAN* \\ Department of Chemistry, Indian Institute of Technology Bombay, Mumbai 400 076, India \\ e-mail: rajaraman@chem.iitb.ac.in
}

MS received 6 November 2013; accepted 24 July 2014

\begin{abstract}
Iron and manganese ions with terminal oxo and hydroxo ligands are discovered as key intermediates in several synthetic and biochemical catalytic cycles. Since many of these species possess vigorous catalytic abilities, they are extremely transient in nature and experiments which probe the structure and bonding on such elusive species are still rare. We present here comprehensive computational studies on eight iron and manganese oxo and hydroxo ( $\mathrm{Fe}^{\mathrm{III} / \mathrm{IV} / \mathrm{V}}-\mathrm{O}, \mathrm{Fe}^{\mathrm{III}}-\mathrm{OH}$ and $\left.\mathrm{Mn}^{\mathrm{III} / \mathrm{IV} / \mathrm{V}}-\mathrm{O}, \mathrm{Mn}^{\mathrm{III}}-\mathrm{OH}\right)$ species using dispersion corrected (B3LYP-D2) density functional method. By computing all the possible spin states for these eight species, we set out to determine the ground state $S$ value of these species; and later on employing MO analysis, we have analysed the bonding aspects which contribute to the high reactivity of these species. Direct structural comparison to iron and manganese-oxo species are made and the observed similarity and differences among them are attributed to the intricate metal-oxygen bonding. By thoroughly probing the bonding in all these species, their reactivity towards common chemical reactions such as $\mathrm{C}-\mathrm{H}$ activation and oxygen atom transfer are discussed.
\end{abstract}

Keywords. Electronic structures and bonding; DFT calculations; high-valent iron and manganese; oxo-hydro complexes.

\section{Introduction}

Heme and non-heme high-valent metal-oxo, metalhydroxo species are gaining significance in recent years as these species have been proposed as key intermediates in a variety of biological processes such as photosystem-II, ${ }^{1}$ peroxidases, ${ }^{2}$ catalases,${ }^{3}$ bleomycin ${ }^{4}$ and naphthalene dioxygenase. ${ }^{5}$ Apart from this, these species are also capable of oxygenating a large variety of organic and inorganic substrates. ${ }^{5}$ These metelloenzymes have inspired a range of biomimetic studies, as these are expected to shed light on complex biological processes and will also help to design new catalysts with increased efficiency and selectivity. These species are also of high relevance to the pharmaceutical industry. ${ }^{7}$ Over the last decade, much attention has been paid to high-valent manganese and iron species due to their potent catalytic abilities and their striking resemblance to enzymatic reactivities. ${ }^{8,9}$ With this motive, synthetic effort to prepare complexes having high-valent metaloxo, peroxo and hydroperoxo units that mimic the catalytic activity of metalloenzymes are made and their catalytic abilities are tested. As iron and manganese atoms are commonly found in the active site of many metalloenzymes, there is a growing interest to study the

*For correspondence structure and reactivity of such species and this is evident from the large body of literature reported in the last decade. ${ }^{8 \mathrm{~d}, 9 \mathrm{a}, \mathrm{b}, 10-12}$

Of particular relevance to our study is the reported by Borovik ${ }^{13}$ and his co-workers who have parallelly performed experimental investigation on manganese and iron complexes with tripodal ligand in the formation of $\mathrm{Fe}^{\mathrm{II} / \mathrm{III} / \mathrm{IV}} / \mathrm{Mn}^{\mathrm{II} / \mathrm{III} / \mathrm{IV}}-\mathrm{O}(\mathrm{H})$ species. As this ligand exhibits unique characteristics to form protective hydrogen bond cavity around the metal- $(\mathrm{O} / \mathrm{OH})$ units, this avoids the formation of $\mu$-oxo bridged dimers. In one of their srudies, ${ }^{13 \mathrm{c}}$ they have reported the reactivity of the $\mathrm{Mn}^{\mathrm{III}}-\mathrm{OH}$ and $\mathrm{Fe}^{\mathrm{III}}-\mathrm{OH}$ complexes towards the $\mathrm{X}-\mathrm{H}(\mathrm{X}=\mathrm{C}, \mathrm{N})$ bond dissociation energies (BDE) and correlated their oxidative abilities to the BDEs. Further, in another study, ${ }^{14}$ the formation of $\mathrm{Mn}^{\mathrm{IV}}$-oxo complex and its spectroscopic features have been discussed and oxygen transfer reaction for the formation of phosphine oxide by these model complexes was tested. Apart from this, peroxo-manganese (III) species and hybrid oxo/hydroxo-manganese (III) species from $\mathrm{Mn}$ (II) precursor have also been synthesized and characterized with the XRD, EPR, FTIR and Mossbauer spectroscopy. ${ }^{15}$

Quantum chemical studies are widely used to gain insight into the chemical bonding and reactivity of heme and non-heme iron and manganese enzymes. ${ }^{16,17}$ In 
the high-valent iron-oxo regime, the most popular species is the $\mathrm{Fe}^{\mathrm{IV}}=\mathrm{O}$ species as its reactivity and structure has been accurately determined. ${ }^{10 a}, 16 \mathrm{~b}, 17$ However in recent years, interest in $\mathrm{Fe}^{\mathrm{V}}=\mathrm{O}$ has increased and spectroscopic ${ }^{8,10 b, c}$ and theoretical characterization of this species ${ }^{16 a, c, d, 18}$ undertaken were undertaken. Besides these species, the presence of $\mathrm{Fe}^{\mathrm{III}}-\mathrm{O}$ and $\mathrm{Fe}^{\mathrm{III}}-\mathrm{OH}$ has also been invoked in some catalytic reactions. ${ }^{8 \mathrm{c}, 9}$ Although $\mathrm{Mn}^{\mathrm{III}}$-O dominates the highvalent manganese-oxo complexes regime, proposal of $\mathrm{Mn}^{\mathrm{IV}}=\mathrm{O}$ performing several catalytic reactions such as $\mathrm{C}-\mathrm{H}$ activation and oxo transfer are evident. ${ }^{12 \mathrm{e}, 19}$ Hydroxo counterparts of the species $\mathrm{Mn}^{\mathrm{II}}-\mathrm{OH},{ }^{20} \mathrm{Mn}^{\mathrm{III}}$ $\mathrm{OH},{ }^{20}$ and $\mathrm{Mn}^{\mathrm{IV}}-\mathrm{OH},{ }^{21 \mathrm{~b}}$ have also been invoked at some occasion to rationalize the reactivity differences. Recently, a detailed computational study was undertaken by our group, ${ }^{16 a}$ in which the formation of $\mathrm{Fe}^{\mathrm{IV}}=\mathrm{O}$ and $\mathrm{Fe}^{\mathrm{V}}=\mathrm{O}$ species with TPA ligand (TPA $=$ tris (2-pyridylmethyl) amine) has been discussed. Earlier, we have also compared the oxidizing ability of $\mathrm{Fe}^{\mathrm{IV}}=\mathrm{O}$ with $\mathrm{Fe}^{\mathrm{IV}}=\mathrm{NTs}$ species and suggested that the $\mathrm{Fe}^{\mathrm{IV}}=\mathrm{NTs}$ species are more reactive than the oxo counterpart. ${ }^{16 \mathrm{~b}}$ Recently, a detailed study of hydrogen atom abstraction by $\mathrm{Mn}^{\mathrm{III}}-\mathrm{O}$ and $\mathrm{Mn}^{\mathrm{IV}}=\mathrm{O}$ complexes was also undertaken to probe the role of basicity in deciding the course of $\mathrm{C}-\mathrm{H}$ activation reaction. ${ }^{12 \mathrm{e}}$

Growing interest on this kind of study encouraged us to explore these high valent metal-oxo, hydroxo species as a possible oxidant in various chemical reactions. We would like to compute and compare the structure and bonding of $\mathrm{Fe}^{\mathrm{IV}}=\mathrm{O}$ with $\mathrm{Fe}^{\mathrm{V}}=\mathrm{O}$ along with $\mathrm{Fe}^{\mathrm{III}}-\mathrm{O}$ and $\mathrm{Fe}^{\mathrm{III}}-\mathrm{OH}$ species. Besides, we want to explore parallelly the structure and bonding in $\mathrm{Mn}^{\mathrm{IV}}=\mathrm{O}$ with $\mathrm{Mn}^{\mathrm{V}} \equiv \mathrm{O}$ along with $\mathrm{Mn}^{\mathrm{III}}-\mathrm{O}$ and $\mathrm{Mn}^{\mathrm{III}}{ }_{-}$ $\mathrm{OH}$ species. By probing the bonding scenario, we wish to comment on its reactivity towards $\mathrm{C}-\mathrm{H}$ bond activation and other chemical reactions. Since much of the iron-oxo chemistry is carried out with tetramino pyridine TPA type ligand, calculations on iron complexes are performed with this ligand backbone. Similarly for manganese-oxo chemistry, $\mathrm{H}_{5}$ bupa ligand system is chosen (bupa $=$ bis $\left[\left(\mathrm{N}^{\prime}\right.\right.$-tert-butylurealy)-N-ethyl $]-(6-$ pivalamido-2-pyridylmethyl)amine).

\section{Computational Details}

We have performed all the calculations using the Gaussian $09,{ }^{22}$ suite of program. The geometries were optimized by using the B3LYP-D2 functional. ${ }^{23}$ The B3LYP-D2 functional incorporates the dispersion proposed by Grimme ${ }^{23}$ Two different basis sets were used; LanL2DZ encompasses a double $\zeta$-quality basis set with the Los Alamos effective core potential for Mn and $\mathrm{Fe}^{24}$ and a $6-31 \mathrm{G}^{*}$ basis set for the other atoms, ${ }^{25}$ optimized geometries were then used to perform singlepoint energy calculations using a $\mathrm{TZVP}^{26}$ basis set on all atoms. Frequency calculations were performed on the optimized structures to verify that they are minima on the potential-energy surface (PES) and also to obtain free energy corrections. The quoted DFT energies are B3LYP-D2 solvation including free-energy corrections with TZVP basis set at the temperature of $298.15 \mathrm{~K}$, unless otherwise mentioned. The optimized geometries were verified by animating frequency by using Molden software. ${ }^{27}$ The solvation energies were computed at the B3LYP-D2 level by using polarizable continuum model with acetonitrile as a solvent. ${ }^{28}$

\section{Results and Discussion}

Structure and bonding of iron-oxo species will be discussed and the details of manganese-oxo species will be elaborated here. This will be followed by a discussion on the cross-comparison of iron and manganese-oxo species.

\subsection{High-valent iron-oxo/hydroxo complexes: \\ Structure, bonding and contribution to reactivity}

3.1a Structure and spin-state energetics of $\mathrm{Fe}^{I I I}-\mathrm{O}$ and $\mathrm{Fe}^{\mathrm{II}}-\mathrm{OH}$ species: Although the $\mathrm{Fe}^{\mathrm{III}}-\mathrm{O}$ species are extremely rare as they have tendency to dimerize and form dinuclear iron-oxo complexes, ${ }^{29}$ there are some reports on iron(III)-oxo complexes where this dimerization has been deliberately avoided. ${ }^{9}$ DFT calculations reveal that sextet state is computed to be the ground state for $\mathrm{Fe}^{\mathrm{III}}-\mathrm{O}$ species and this is consistent with the earlier reports. ${ }^{9 \mathrm{c}}$ The quartet state lies only at $17.9 \mathrm{~kJ} / \mathrm{mol}$ higher in energy, while a low-spin $\mathrm{Fe}^{\mathrm{III}}=\mathrm{O}$ lies at $92.5 \mathrm{~kJ} / \mathrm{mol}$ higher in energy. Optimized structure of the $h s \mathrm{Fe}^{\mathrm{III}}-\mathrm{O}$ and its corresponding spin density plot are shown in figure $1 \mathrm{a}$ and $\mathrm{b}$. The FeO bond length is computed to be $1.732 \AA$ and correspond rather to a single Fe-L covalent bond character. Since all the d-orbitals are half-filled, this significantly limits the ability of strong $\sigma$ - and $\pi$-donation and this leads to a longer and weaker $\mathrm{Fe}-\mathrm{O}$ bonds for the $\mathrm{Fe}^{\mathrm{III}}-\mathrm{O}$ species. With slightly different ligand architecture, a Fe $\mathrm{Fe}^{\mathrm{III}}-\mathrm{O}$ complex has been reported with the $\mathrm{Fe}-\mathrm{O}$ bond length of $1.813 \AA^{9 a, b}$ and this is comparable to our calculated values. The $\mathrm{Fe}-\mathrm{O}$ bond length elongates to $1.802 \AA$ for doublet and $1.657 \AA$ for the quartet states. Spin density of 3.95 has been detected on the iron centre while oxygen gains $\sim 0.8$ spin density. Similarly, all the 


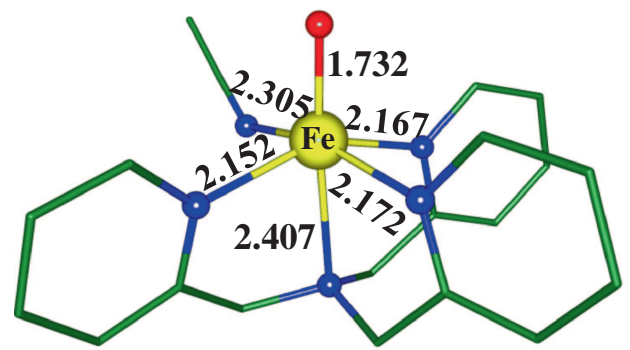

(a)

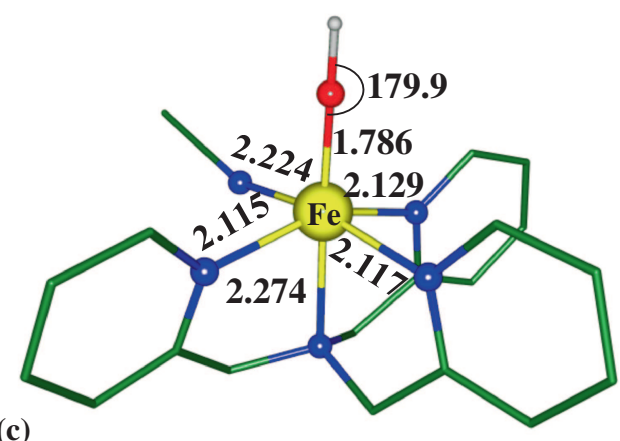

(c)

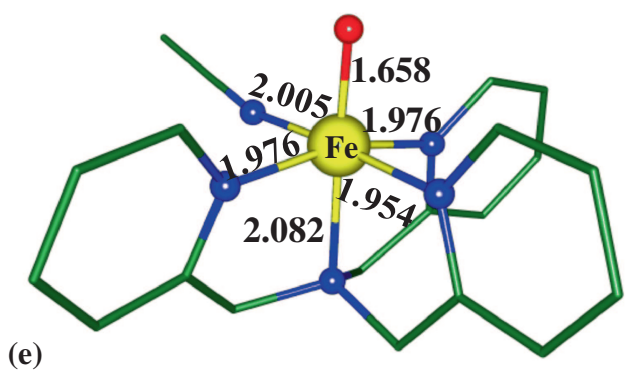

(e)

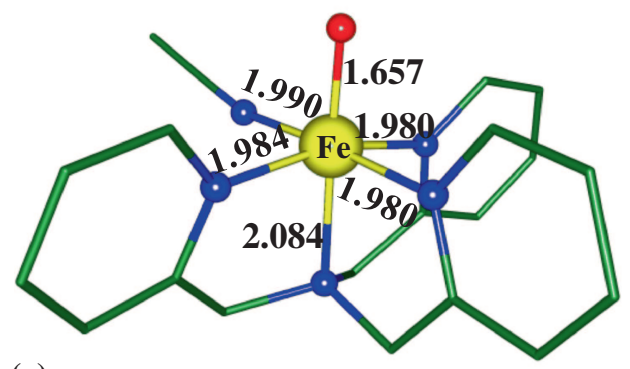

(g)

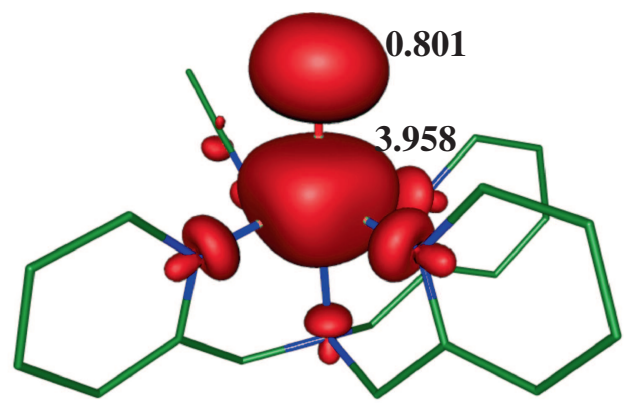

(b)

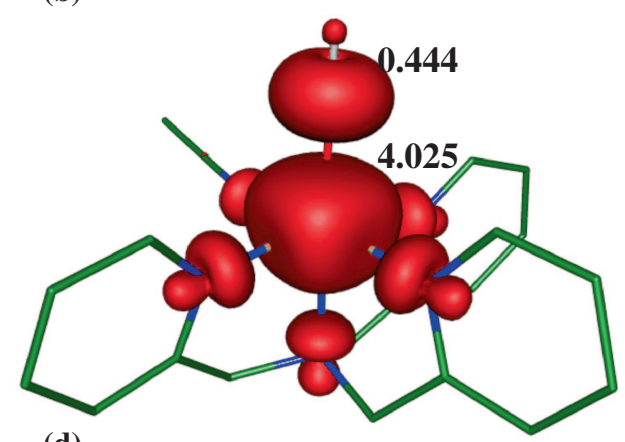

(d)
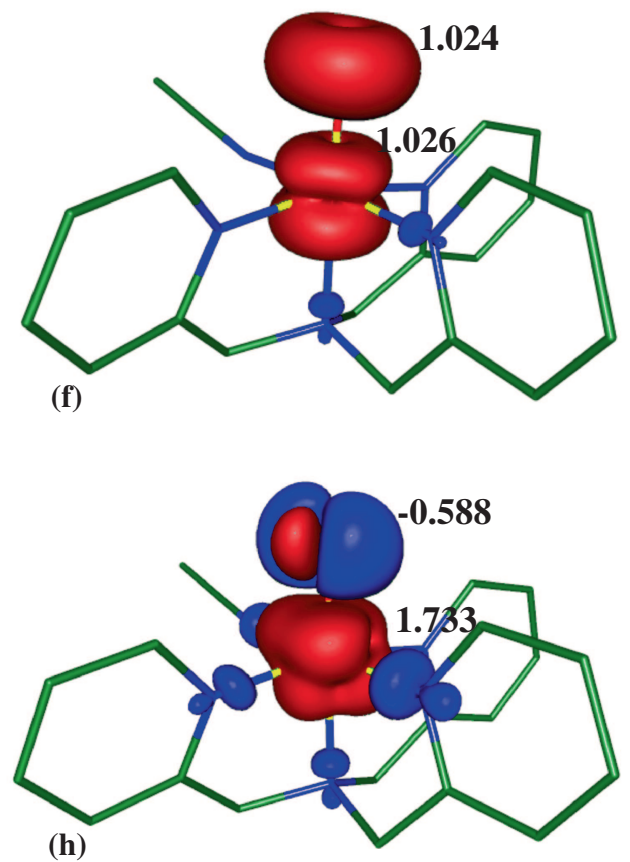

Figure 1. B3LYP-D2 optimized structures and spin density plots of the ground state of $(\mathbf{a}, \mathbf{b}) \mathrm{Fe}^{\mathrm{III}}-\mathrm{O},(\mathbf{c}, \mathbf{d}) \mathrm{Fe}^{\mathrm{III}}-\mathrm{OH},(\mathbf{e}, \mathbf{f}) \mathrm{Fe}^{\mathrm{IV}}=\mathrm{O}$ and $(\mathbf{g}, \mathbf{h}) \mathrm{Fe}^{\mathrm{V}}=\mathrm{O}$ species.

coordinated nitrogen atoms also gain spin density via spin delocalization mechanism.

Significant spin density on the oxygen center reveals that the formal $\mathrm{Fe}^{\mathrm{III}}-\mathrm{O}$ species rather behaves as an $\mathrm{Fe}^{\mathrm{IV}}$ oxyl-radical species. Reactivity of $\mathrm{Fe}^{\mathrm{IV}}$-oxyl-radical species has been much debated in the recent literature. ${ }^{30}$ Since our calculations predict the formal $\mathrm{Fe}^{\mathrm{III}}-\mathrm{O}$ as a $\mathrm{Fe}^{\mathrm{IV}}$-radical complex, a very high reactivity can be expected for this species, although no octahedral $\mathrm{Fe}^{\mathrm{III}}-\mathrm{O}$ complexes are reported so far. Compared to the $\mathrm{Fe}^{\mathrm{III}}-\mathrm{O}$ species, the $\mathrm{Fe}^{\mathrm{III}}-\mathrm{OH}$ species are more abundant in the literature, ${ }^{9,31}$ particularly as a product of $\mathrm{C}-\mathrm{H}$ activation by the $\mathrm{Fe}^{\mathrm{IV}}=\mathrm{O}$ complexes. ${ }^{31}$ Optimized structure of $\mathrm{Fe}^{\mathrm{III}}-\mathrm{OH}$ along with computed spin density plot is shown in figure $1 \mathrm{c}$ and d. Similar to the oxo complex, $S=5 / 2$ is found to be the ground state for 
this species with $S=3 / 2$ and $1 / 2$ lying at 41.1 and $21.1 \mathrm{~kJ} / \mathrm{mol}$, respectively. The Fe-O bond length elongates to $1.786 \AA$ compared to the corresponding oxo complexes and this is due to relatively weaker $\mathrm{Fe}-\mathrm{O} \pi$ bonding for the hydroxo species. A longer Fe-O bond also facilitates a shorter axial Fe-N bond in the hydroxo species. For the $S=5 / 2$ state, the Fe-O-H bond angle is computed to be almost linear, while it is bent for the $S=3 / 2$ and $1 / 2$ states. This degree of bending is found to directly correlate to the $\mathrm{Fe}-\mathrm{O} \pi$-bond character. Since in the $S=5 / 2$ state, the $\mathrm{d}_{\mathrm{xz}}$ and $\mathrm{d}_{\mathrm{yz}}$ orbitals are halffilled, the oxygen $p_{x}$ and $p_{y}$ orbitals overlap with them in $\pi$-fashion forming strong $\pi$-bond (see scheme 1).

As both the orbitals are engaged, hydrogen atom coordinates with $\mathrm{p}_{\mathrm{z}}$ orbital making $\mathrm{Fe}-\mathrm{O}-\mathrm{H}$ angle closer to 180 degrees. However, for $S=3 / 2(S=1 / 2)$ state, since one(two) $t_{2 g}$ orbital(s) is(are) doubly occupied, this significantly hinders $\mathrm{Fe}-\mathrm{O} \pi$-bond leading to availability of $\mathrm{p}_{\mathrm{x}} / \mathrm{p}_{\mathrm{y}}$ orbital for hydrogen coordination and hence leads to Fe-O-H bending. This suggests that as the spin state $S$ value decreases, the $\pi$-bonding character of the $\mathrm{Fe}-\mathrm{O}$ bond also decreases and this is clearly visible in the elongation of $\mathrm{Fe}-\mathrm{O}$ bond as we move down from $S=5 / 2$ to $S=1 / 2$ species.

Spin density of the Fe atoms are found to be nearly same compared to the $\mathrm{Fe}^{\mathrm{III}}-\mathrm{OH}$ species, while a drastic reduction on the spin density of oxygen is visible. The supposedly excess spin density on $\mathrm{Fe}$ is found to be distributed to the coordinated nitrogen atoms, leading to larger spin densities on the pyridine $\mathrm{N}$-nitrogen atoms for the $\mathrm{Fe}^{\mathrm{III}}-\mathrm{OH}$ species compared to $\mathrm{Fe}^{\mathrm{III}}-\mathrm{O}$ species (see figure $1 \mathrm{~d}$ vs. b).

\section{1b Structure and spin-state energetics of $F e^{I V}=O$} species: One electron oxidation of $\mathrm{Fe}^{\mathrm{III}}-\mathrm{O}$ yields the popular $\mathrm{Fe}^{\mathrm{IV}}=\mathrm{O}$ species. Numerous theoretical and experimental studies have been undertaken on this

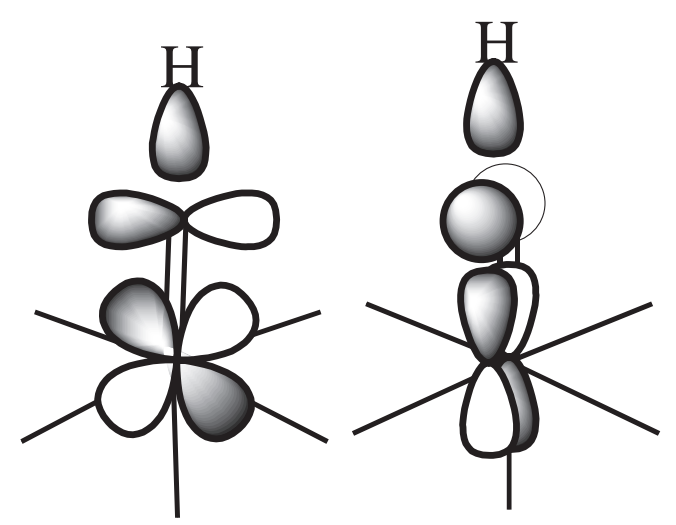

Scheme 1. Frontier $\pi$-orbitals of $\mathrm{Fe}^{\mathrm{III}}-\mathrm{OH}$ species at $S=5 / 2$ spin surface. species and even X-ray structures are available with slightly different ligand backbone. ${ }^{18 \mathrm{c}}$ For this species, we computed all possible spin states such as quintet, triplet and singlet states and triplet state is found to be the ground state. This is consistent with earlier experimental reports. ${ }^{10 a, 18}$ The quintet and singlet states are calculated to be 17.9 and $155.7 \mathrm{~kJ} / \mathrm{mol}$ higher in energy compared to the ground state triplet. Optimized structure of the triplet state along with its spin density is shown in figure 1e and $\mathrm{f}$. The Fe-O bond here is computed as $1.658 \AA$ and this is in agreement with the $\mathrm{Fe}-\mathrm{O}$ bond length determined from the X-ray structure ${ }^{10 a, 18}$ $(1.646 \AA)$. A shorter bond length indicates a conventional double bond character between iron and oxygen atom with one $\sigma$ and one $\pi$ bond character. Since for the $S=1$ Fe state, the electronic configuration is computed to be $\left(\delta_{\mathrm{xy}}\right)^{2}\left(\pi_{\mathrm{xz}}\right)^{* 1}\left(\pi_{\mathrm{yz}}\right)^{* 1}$ (see figure 2) and a strong $\pi$ character between oxygen p-orbitals and $\mathrm{Fe} \mathrm{d}_{\mathrm{xz}}$ and $\mathrm{d}_{\mathrm{yz}}$ orbitals are detected for this species. The Fe-O bond length in the quintet state is computed as $1.650 \AA$, which is slightly shorter than that of the triplet state. At ground state, a spin density of 1.026 been detected at the iron center, while an equal amount of spin density is also detected at the oxygen atom and this suggests a $\mathrm{Fe}^{\mathrm{V}}=\mathrm{O}^{\bullet}$ rather than a formal $\mathrm{Fe}^{\mathrm{IV}}=\mathrm{O}$ type for this species. The calculated energetics and bonding is in agreement with previous theoretical results. ${ }^{16}$ A significant spin density (1.024) available on the oxygen atom facilitates the $\mathrm{C}-\mathrm{H}$ activation or electrophilic attack on aliphatic/aromatic hydrocarbon. ${ }^{16 a, 30,32}$

3.1c Structure and spin-state energetics of $\mathrm{Fe}^{V}=O$ species: Further, one electron oxidation of $\mathrm{Fe}^{\mathrm{IV}}=\mathrm{O}$ generates a transient $\mathrm{Fe}^{\mathrm{V}}=\mathrm{O}$ species. Generally, the $\mathrm{Fe}^{\mathrm{V}}=\mathrm{O}$ species are generated from the $\mathrm{Fe}^{\mathrm{III}}-\mathrm{OOH}$ species by heterolytic cleavage of the O. .O bond. ${ }^{8 a, b}$ Although, the detection of $\mathrm{Fe}^{\mathrm{V}}=\mathrm{O}$ species is rare as they are extremely reactive, strong evidence for the existence of $\mathrm{Fe}^{\mathrm{V}}=\mathrm{O}$ species is documented. ${ }^{10 \mathrm{~b}, \mathrm{c}}$ Optimized structure of $\mathrm{Fe}^{\mathrm{V}}=\mathrm{O}$ species $(S=1 / 2)$ is shown in figure $1 \mathrm{~g}$. Due to SCF convergence problem, the highspin $S=3 / 2$ state could not be optimized. The ground state for this species is $S=1 / 2$ as detected in an earlier EPR spectroscopy study. ${ }^{10 b, c}$ The Fe-O bond length for the $S=1 / 2$ state is computed to be $1.657 \AA$ and this is also consistent with previous theoretical studies. ${ }^{10 \mathrm{~b}, \mathrm{c}, 16 \mathrm{a}, 19}$ and the X-ray absorption data reported with a slightly different ligand backbone. ${ }^{10 \mathrm{~b}}$ The Fe-O bond length in this species is strikingly similar to the $\mathrm{Fe}^{\mathrm{IV}}=\mathrm{O}$ complex, suggesting that electron deficiency in $\mathrm{Fe}^{\mathrm{V}}=\mathrm{O}$ does not induce a stronger $\mathrm{Fe}-\mathrm{O}$ bond. Spin density is on the iron and oxygen are computed to be 1.733 and -0.588 , respectively (see figure $1 \mathrm{~h}$ ). Significant 


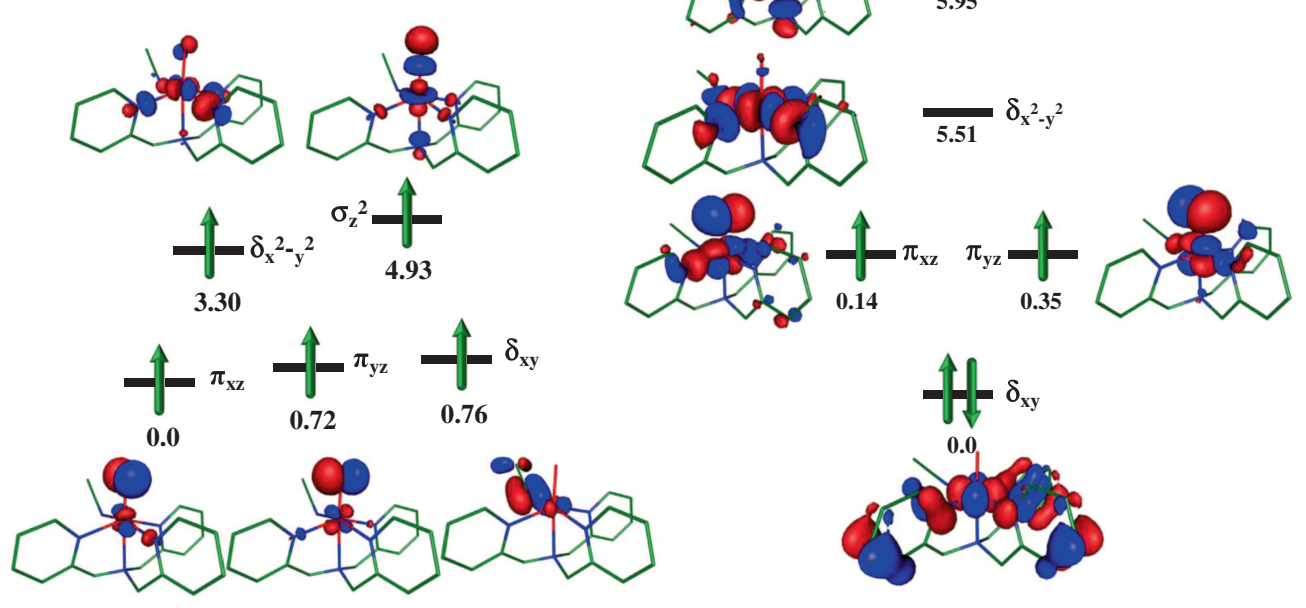

Figure 2. DFT-computed eigenvalue plots along with DFT-computed d-based MOs for the $\mathrm{Fe}^{\mathrm{III}}-\mathrm{O}$ (left) and $\mathrm{Fe}^{\mathrm{IV}}=\mathrm{O}$ species.

reduction in the equatorial $\mathrm{Fe}-\mathrm{N}$ distances is visible for the $\mathrm{Fe}^{\mathrm{V}}=\mathrm{O}$ species compared to that of the $\mathrm{Fe}^{\mathrm{IV}}=\mathrm{O}$ species. Spin densities on Fe and oxygen atoms are of opposite signs. This species can simultaneously accept spin-up and spin-down electrons from the substrates. This feature is absent in all the computed species and could be a possible reason for the vigorous oxidative ability of the $\mathrm{Fe}^{\mathrm{V}}=\mathrm{O}$ species. ${ }^{16 \mathrm{a}, 19}$

\subsection{High-valent manganese-oxo/hydroxo complexes: Structure, bonding and contribution to reactivity}

3.2a Structure and spin-state energetics of $\mathrm{Mn}^{\mathrm{II}}-\mathrm{O}$ and $\mathrm{Mn}^{I I I}-\mathrm{OH}$ species: Unlike the iron counterpart, the $\mathrm{Mn}^{\mathrm{III}}-\mathrm{O}$ and $\mathrm{Mn}^{\mathrm{III}}-\mathrm{OH}$ species are reported in literature, particularly with ligands possessing H-bonding cavities to prevent dimerization. ${ }^{13 a}$ The optimized structure and spin density plot of the $\left[\mathrm{Mn}^{\mathrm{III}} \mathrm{H}_{3} \text { bupa }(\mathrm{O})\right]^{-}$ and $\left[\mathrm{Mn}^{\mathrm{III}} \mathrm{H}_{3} \text { bupa }(\mathrm{OH})\right]^{-}$are shown in figure $3 \mathrm{a}-\mathrm{d}$. For both the cases, $S=2$ is found to be the ground state with the triplet and the singlet states lying much higher in energy (105.9 and $160.5 \mathrm{~kJ} / \mathrm{mol}$ for $\mathrm{Mn}^{\mathrm{III}}-\mathrm{OH}$ and $127.2 \mathrm{~kJ} / \mathrm{mol}$ for triplet $\mathrm{Mn}^{\mathrm{III}}-\mathrm{O}$ species). The $\mathrm{Mn}-\mathrm{O}$ bond length in $\mathrm{Mn}^{\mathrm{III}}-\mathrm{O}$ is found to be $1.731 \AA$, while the same bond is elongated to $1.816 \AA$ for the hydroxo complex indicating variation in the degree of $\pi$-bonding character. Although experimental structures for this particular ligand is unavailable, for a structurally similar ligand, X-ray structure for both the species is reported; where the $\mathrm{Mn}-\mathrm{O}$ bond lengths are estimated to be $1.771 \AA$ and $1.872 \AA$ and this matches with the computed results. ${ }^{13 a}$ Spin density on the Mn atoms for the oxo and hydroxo species are estimated to be 3.681 and 3.762 , respectively indicating that unpaired electrons are largely localized on the metal centers. The oxygen atom has 0.157 and 0.050 spin densities for the oxo and hydrooxo species, respectively; and this illustrates that oxygen gains very little spin density compared to it iron counterparts. The eigenvalue plot along with orbital diagram for the $\mathrm{Mn}^{\mathrm{III}}-\mathrm{O}$ is shown in figure 4. For trigonal-bipyramidal (TBP) geometry, the frontier orbitals are $\mathrm{d}_{\mathrm{xy}}$ and $\mathrm{d}_{x^{2}-y^{2}}$, while $\mathrm{d}_{\mathrm{xz}}$ and $\mathrm{d}_{\mathrm{yz}}$ orbitals are the lowest lying within the d-block. This stabilization of $\mathrm{d}_{\mathrm{xz}}$ and $\mathrm{d}_{\mathrm{yz}}$ in TBP geometry significantly reduces the $\mathrm{Mn}-\mathrm{O} \pi$ character compared to that of the $\mathrm{Fe}-\mathrm{O}$ bond. For the $\mathrm{Mn}^{\mathrm{III}}-\mathrm{OH}$ species, naturally even weaker Mn-O $\pi$ bonding is expected leading to weaker and longer $\mathrm{Mn}-\mathrm{O}$ bonds. It is to be noted here that the $\mathrm{H}$-bonding interaction present in the $\mathrm{Mn}^{\mathrm{III}}-\mathrm{O}$ and the $\mathrm{Mn}^{\mathrm{III}}-\mathrm{OH}$ species are non-innocent and found to influence the nature of the oxygen atoms in this ligand architecture. ${ }^{13 a}$ There are three strong $\mathrm{H}$-bonds to the oxygen atom of the oxo group and these $\mathrm{O}-\mathrm{H}$ distances are found to be $1.820,1.806$ and $1.522 \AA$. One of the $\mathrm{O} \ldots \mathrm{H}$ bonds is found to be stronger than the other two and this is due to differential donating abilities of the corresponding nitrogen atoms.

In case of $\mathrm{Mn}^{\mathrm{III}}-\mathrm{OH}$ species, the two MnO...H distances are found to be $1.844,1.823 \AA$, while the third $(\mathrm{MnO}) \mathrm{H}$. . . N hydrogen bonding distance is found to be $1.772 \AA$. For both the species, very strong intramolecular hydrogen bonding is detected and this is supported by the X-ray structure (short N. . .O distances). Besides, the hydrogen bonding strength in $\mathrm{Mn}^{\mathrm{III}}-\mathrm{O}$ is found to be stronger than that of the $\mathrm{Mn}^{\mathrm{III}}-\mathrm{OH}$ species. 


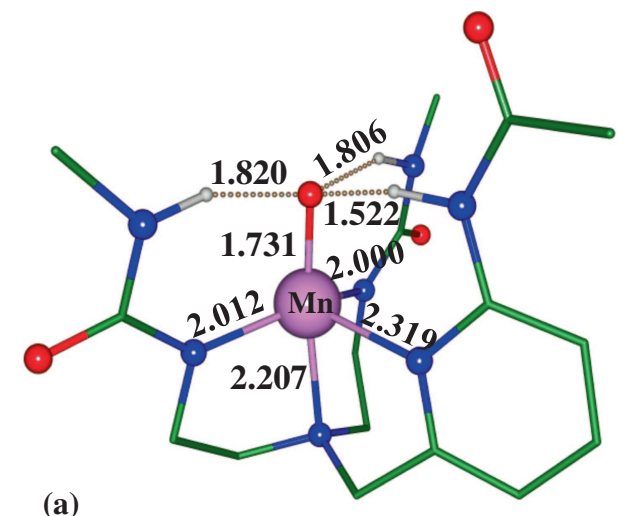

(a)
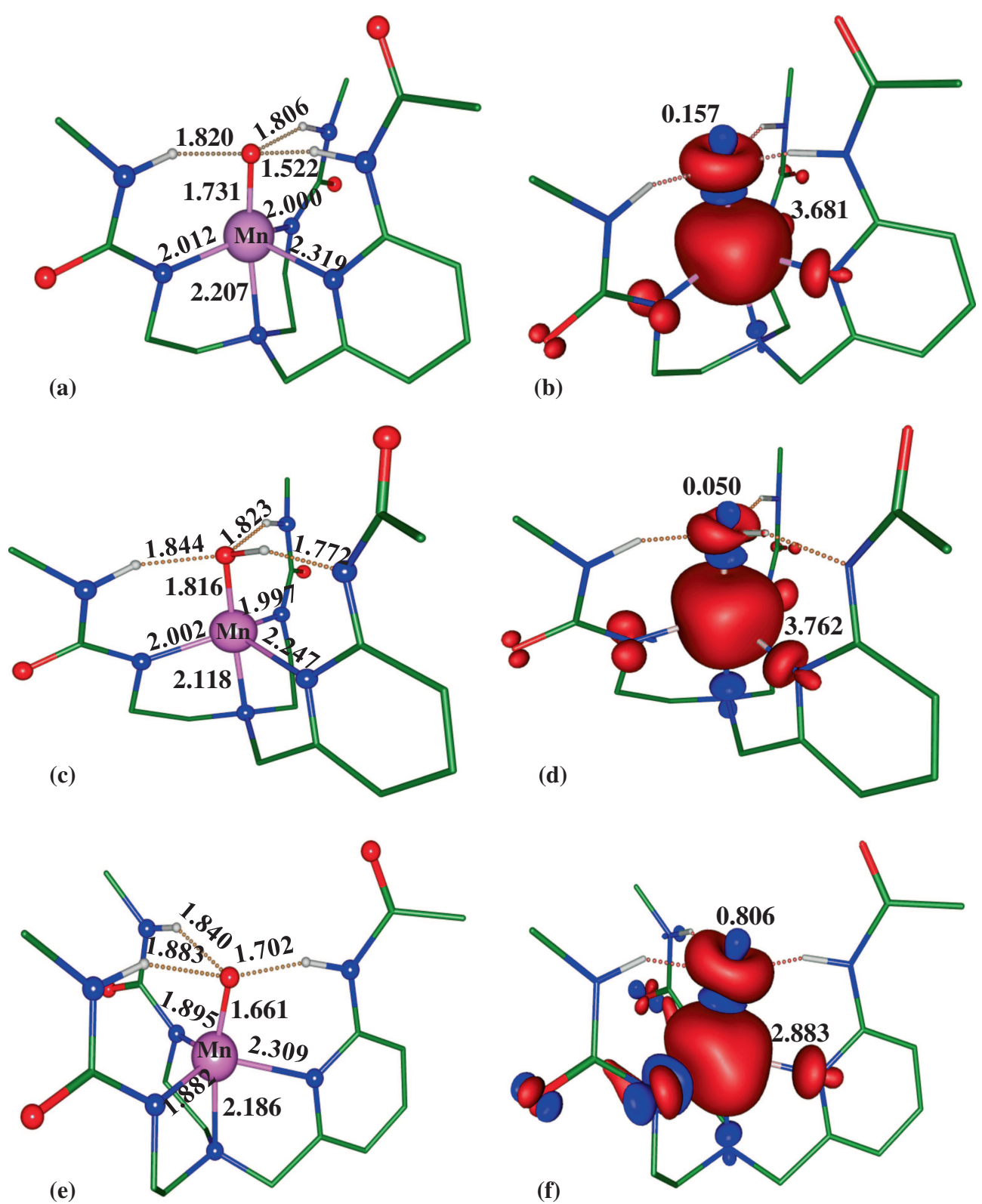

Figure 3. B3LYP-D2 computed structures and spin density plots for the ground state of $(\mathbf{a}, \mathbf{b}) \mathrm{Mn}^{\mathrm{III}}-\mathrm{O},(\mathbf{c}, \mathbf{d}) \mathrm{Mn}^{\mathrm{III}}-\mathrm{OH}$ and $(\mathbf{e}, \mathbf{f}) \mathrm{Mn}^{\mathrm{IV}}=\mathrm{O}$ species respectively.

3.2b Structure and spin-state energetics of $\mathrm{Mn}^{I V}=O$ species: Optimized structure of $\left[\mathrm{Mn}^{\mathrm{IV}} \mathrm{H}_{3}\right.$ bupa(O) along with the computed spin density plot is shown in figure $3 \mathrm{e}$ and $\mathrm{f}$. For this species as well a high spin, $S=3 / 2$ is computed to be the ground state with $S=1 / 2$ lying at $87.2 \mathrm{~kJ} / \mathrm{mol}$ higher in energy. The $\mathrm{Mn}-\mathrm{O}$ bond length is computed to be $1.661 \AA$, although X-ray structure is unavailable for this complex, the calculated bond length agrees well with earlier theoretical report on the $\mathrm{Mn}^{\mathrm{IV}}=\mathrm{O}$ possessing similar structural motif. Further, this $\mathrm{Mn}-\mathrm{O}$ bond length is found to be shorter than the $\mathrm{Mn}^{\mathrm{III}}-\mathrm{O}$ species by $0.07 \AA$ and this indicates a rather conventional double bond character similar to that suggested for analogues of $\mathrm{Fe}^{\mathrm{IV}}=\mathrm{O}$ complexes. ${ }^{14}$ Besides, for the TBP $\mathrm{Mn}^{\mathrm{IV}}=\mathrm{O}$ species, Jahn-Teller distortion ${ }^{13 \mathrm{a}}$ is operational, and here $d_{x}^{2}-y^{2}$ orbital is found to be lower in energy compared to $d_{x y}$ orbital leading to one long and two short $\mathrm{Mn}-\mathrm{N}_{\mathrm{eq}}$ bonds (see figure 3e). Spin density on the $\mathrm{Mn}$ atoms is found to be 2.883 along with a significant spin density also on the oxygen atom (0.806). The Mn atoms donate significant spin density to the oxygen atom via spin delocalization mechanism and at the same time polarize the equatorial nitrogen atoms to gain further spin density.

This dual role played by the $\mathrm{Mn}$ ion leads to $\rho_{\mathrm{MnO}}$ group spin density of 3.689 which is larger than the expected value of 3.0. Significant spin density on oxygen atom reveals a rather $\mathrm{Mn}^{\mathrm{IV}}$-oxyl radical character 


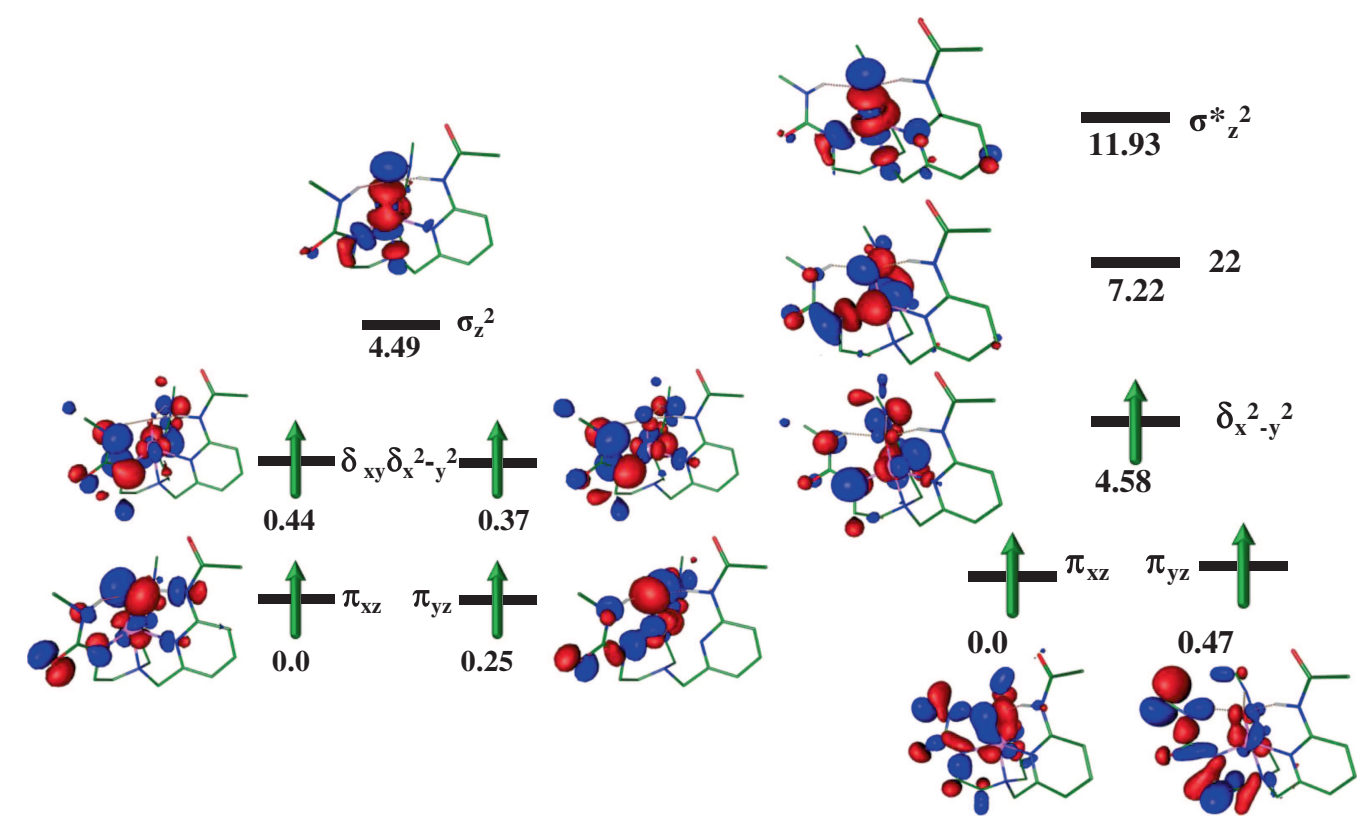

Figure 4. DFT-computed eigenvalue plots along with DFT-computed d-based MOs for the $\mathrm{Mn}^{\mathrm{III}}-\mathrm{O}$ (left) and $\mathrm{Mn}^{\mathrm{IV}}=\mathrm{O}$ (right) species.

for the $\mathrm{Mn}^{\mathrm{IV}}=\mathrm{O}$ species and this is similar again to that of the $\mathrm{Fe}^{\mathrm{IV}}=\mathrm{O}$ complex.

3.2c Structure and spin-state energetics of $M n^{V} \equiv O$ species: Optimized structure of the $\left[\mathrm{Mn}^{\mathrm{V}} \mathrm{H}_{3}\right.$ bupa $(\mathrm{O})]^{+}$complex for the $S=0$ state is shown in figure 5 . The $\mathrm{Mn}-\mathrm{O}$ bond length is very short here and amounts to $1.579 \AA$ suggesting a conventional triplet bond between $\mathrm{Mn}$ and oxygen atoms $\left(\mathrm{Mn}^{\mathrm{V}} \equiv \mathrm{O}\right)$. Unlike any other metal-oxo species studied, the $\mathrm{N}-\mathrm{Mn}-\mathrm{O}$ bond is found to be nonlinear and this might be associated with the difference in the H-bonding strength. Although, $\mathrm{Mn}^{\mathrm{V}} \equiv \mathrm{O}$ species were detected using experimental techniques ${ }^{33}$ earlier, X-ray structure is unavailable and thus the computed structure cannot be correlated to

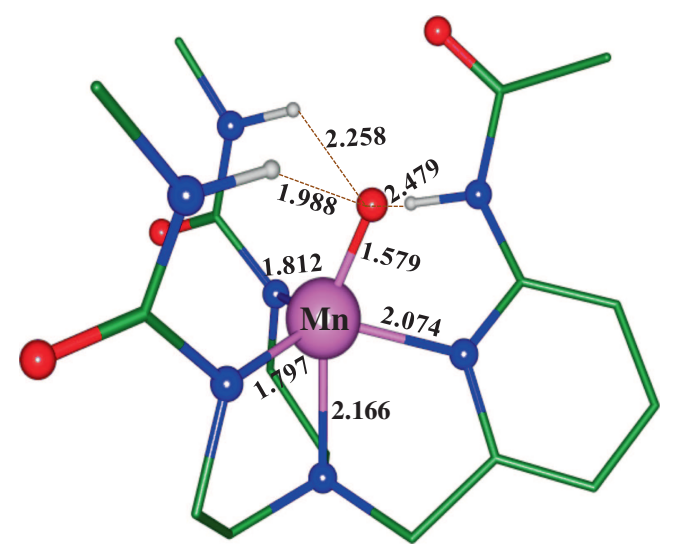

Figure 5. B3LYP-D2 computed structure for the $\mathrm{Mn}^{\mathrm{V}} \equiv \mathrm{O}$ species. experimental findings. Besides, due to SCF convergence problem, $S=1$ high spin state could not be optimized for this species.

\subsection{Fe-oxo vs. Mn-oxo complexes: Direct structural relationship and diverse electronic requirements}

Reactivity of the metal-oxo complexes is strongly correlated to the basicity of the oxo species, which in turn correlates to the metal-oxygen bond lengths. Comparison of metal-oxygen bond lengths among the computed species will unfold intriguing relationship between the structure and electronic configurations. Although, both $\mathrm{Fe}^{\mathrm{III}}-\mathrm{O}$ and $\mathrm{Mn}^{\mathrm{III}}-\mathrm{O}$ species possess electronically different states, the $\mathrm{M}-\mathrm{O}$ bond lengths are comparable (1.732 $\AA$ vs. $1.731 \AA$ for $\mathrm{Fe}-\mathrm{O}$ and $\mathrm{Mn}-\mathrm{O}$, respectively). This is associated with the $\pi$-bonding abilities of these two species. Since the additional unpaired electron in the $\mathrm{Fe}^{\mathrm{III}}-\mathrm{O}$ resides in $\delta$-type $\mathrm{d}_{x^{2}-y^{2}}$ orbital, no additional M-O bond characters are expected for $\mathrm{Fe}-\mathrm{O}$ compared to the $\mathrm{Mn}-\mathrm{O}$ orbital and this is reflected in the computed structure. However, longer $\mathrm{M}-\mathrm{N}_{\mathrm{eq}}$ distances are expected for the $\mathrm{Fe}^{\mathrm{III}}-\mathrm{O}$ species compared to the $\mathrm{Mn}$ counterpart and this is again nicely reflected in the computed results (average $\mathrm{M}-\mathrm{N}_{\mathrm{eq}} 2.199 \AA$ vs $2.110 \AA$ for $\mathrm{Fe}^{\mathrm{III}}-\mathrm{O}$ and $\mathrm{Mn}^{\mathrm{III}}-\mathrm{O}$, respectively). The $\mathrm{M}-\mathrm{O}$ bond length comparison drastically changes as we move from oxo to hydroxo counterparts. For the $\mathrm{Fe}^{\mathrm{III}}-\mathrm{OH}$ and $\mathrm{Mn}^{\mathrm{III}}-\mathrm{OH}$ species, the $\mathrm{M}-\mathrm{O}$ distances are $1.786 \AA$ and $1.816 \AA$, respectively. The clues to these differences lie in the $\mathrm{M}-\mathrm{O}-\mathrm{H}$ angles, where $\mathrm{Fe}-\mathrm{O}-\mathrm{H}$ angles are found 
to be linear, while Mn-O-H angles are bent. This suggests that the $\mathrm{Mn}-\mathrm{O} \pi$ bonding characters are significantly influenced by the presence of the hydrogen atom and this leads to longer than expected $\mathrm{Mn}-\mathrm{O}$ bonds in the $\mathrm{Mn}^{\mathrm{III}}-\mathrm{OH}$ species.

Similar to the above context, the $\mathrm{Fe}^{\mathrm{IV}}=\mathrm{O}$ and $\mathrm{Mn}^{\mathrm{IV}}=\mathrm{O}$ species $\mathrm{M}-\mathrm{O}$ bond lengths also match each other $(1.658 \AA$ vs. $1.661 \AA \mathrm{Fe}-\mathrm{O}$ and $\mathrm{Mn}-\mathrm{O}$, respectively). The ground state electron configurations here are $\mathrm{Fe}^{\mathrm{IV}}=\mathrm{O}\left(\delta_{\mathrm{xy}}\right)^{2}\left(\pi_{\mathrm{xz}}\right)^{* 1}\left(\pi_{\mathrm{yz}}\right) * 1$ (see figure 2, right) and $\mathrm{Mn}^{\mathrm{IV}}=\mathrm{O}\left(\pi_{\mathrm{xz}}\right)^{* 1}\left(\pi_{\mathrm{yz}}\right)^{* 1}\left(\delta_{\mathrm{xy}}\right)^{1}$ (see figure 4 , right). Again, the additional electron in Fe resides in $\delta$ type orbital leading to similar $\mathrm{Fe}-\mathrm{O}$ bond lengths. For the $\mathrm{Fe}^{\mathrm{V}}=\mathrm{O}$ and $\mathrm{Mn}^{\mathrm{V}} \equiv \mathrm{O}$, the $\mathrm{M}-\mathrm{O}$ bond lengths differ significantly (1.657 $\AA$ vs. $1.579 \AA$ ). The computed ground state electron configurations here are $\mathrm{Fe}^{\mathrm{V}}=\mathrm{O}$ $\left(\delta_{\mathrm{xy}}\right)^{2}\left(\pi_{\mathrm{xz}}\right)^{* 1}$ and $\mathrm{Mn}^{\mathrm{V}} \equiv \mathrm{O}\left(\delta_{\mathrm{xy}}\right)^{2}$. An extra electron in the Fe center adds to the $\pi$-antibonding $d_{x z}$ orbital and this leads to a longer $\mathrm{Fe}-\mathrm{O}$ bond in the $\mathrm{Fe}^{\mathrm{V}}=\mathrm{O}$ species.

A second feature which is strongly correlated to the $\mathrm{C}-\mathrm{H}$ activation by these species are the spin densities on the metal and the oxygen centers. The amount of spin density on the oxygen center particularly reveals the electrophilic/nucleophilic nature of the metal-oxygen bonds. Generally, spin densities on the iron complexes are strongly delocalized compared to that of the manganese complexes (see figures 1 and 3). Of particular interest here is the formation of oxyl-radical character at the ferryl oxygen centers with all the species computed, while the same behaviour is detected only for the $\mathrm{Mn}^{\mathrm{IV}}=\mathrm{O}$ species. This invariably suggests that all the $\mathrm{Fe}$ and $\mathrm{Mn}^{\mathrm{IV}}=\mathrm{O}$ complexes are nucleophilic in nature while other $\mathrm{Mn}$ species such as $\mathrm{Mn}^{\mathrm{III}}-\mathrm{O}, \mathrm{Mn}^{\mathrm{III}}$ $\mathrm{OH}$ and $\mathrm{Mn}^{\mathrm{V}} \equiv \mathrm{O}$ are electrophilic in nature. Several experimental studies undertaken individually on these species essentially support our claim. ${ }^{12 \mathrm{e}, 16 \mathrm{~b}, 20 \mathrm{a} \text {, }}$

\section{Conclusions}

High-valent metal-oxo complexes are of great interest as they possess tremendous catalytic abilities and are model complexes of several metalloenzymes. Here, we have undertaken detailed density functional studies to probe structure, spin density and bonding in $\mathrm{Fe}^{\mathrm{III}}-\mathrm{O}, \mathrm{Fe}^{\mathrm{III}}-\mathrm{OH}, \mathrm{Fe}^{\mathrm{IV}}=\mathrm{O}, \mathrm{Fe}^{\mathrm{V}}=\mathrm{O}, \mathrm{Mn}^{\mathrm{III}}-\mathrm{O}, \mathrm{Mn}^{\mathrm{III}}-\mathrm{OH}$, $\mathrm{Mn}^{\mathrm{IV}}=\mathrm{O}$ and $\mathrm{Mn}^{\mathrm{V}} \equiv \mathrm{O}$ species. The conclusions derived from this study are summarized below.

(i) Dispersion corrected hybrid B3LYP-D2 functional yields Fe and Mn-oxo structures, which are in excellent agreement with the available $\mathrm{X}$-ray structure. (ii) Significant decrease in the $\mathrm{M}-\mathrm{O}$ bond lengths are encountered as the oxidation state of the metal ions increases from +3 to +5 . This decrease in bond length is attributed to strong $\pi$-bonding abilities of the species possessing higher oxidation state.

(iii) This degree of bending in the $\mathrm{Fe}^{\mathrm{III}}-\mathrm{OH}$ species is found to directly correlate to the $\mathrm{Fe}-\mathrm{O}$ $\pi$-bond character, while in the $\mathrm{Mn}^{\mathrm{III}}-\mathrm{OH}$ species, the hydrogen atom is bent in all the three spin states because of the hydrogen bond cavity around the $\mathrm{Mn}-\mathrm{OH}$ unit.

(iv) Spin densities on the oxygen atom in the ironoxo and manganese-oxo complexes reveal the nature of these species during a course of the reaction. Our study suggests that all the studied iron-oxo/hydroxo and the $\mathrm{Mn}^{\mathrm{IV}}=\mathrm{O}$ species are nucleophilic in nature while other manganese-oxo species such as $\mathrm{Mn}^{\mathrm{III}}-\mathrm{O}, \mathrm{Mn}^{\mathrm{III}}-\mathrm{OH}$ and $\mathrm{Mn}^{\mathrm{V}} \equiv \mathrm{O}$ are electrophilic in nature.

\section{Acknowledgements}

GR thanks for financial support from the Government of India through the Department of Science and Technology (SR/S1/IC-41/2010; SR/NM/NS-1119/2011) and Indian Institute of Technology, Bombay to access the high performance computing facility. BP thanks UGC New Delhi for JRF fellowship, AA thanks CSIR, New Delhi for JRF fellowship and NV thanks DST for FAST TRACK fellowship.

\section{References}

1. (a) Yachandra V K, Sauer K and Klein M P 1996 Chem. Rev. 96 2927; (b) Tommos C and Babcock G T 1998 Acc. Chem. Res. 3118 and references therein; (c) Pecoraro V L, Baldwin M J, Caudle M T, Hsieh W Y and Law N A 1998 Pure Appl. Chem. 70 925; (d) Tang X S, Ball J A, Randall D W, Force D A, Diner B A and Britt R D 1996 J. Am. Chem. Soc. 118 7638; (e) Gilchrist Jr. M L, Ball J A, Randall D W and Britt R D 1995 Proc. Natl. Acad. Sci. 929545

2. Nicks R J, Ray G B, Fish K M, Spiro T G and Groves J T 1991 J. Am. Chem. Soc. 1131838

3. (a) Pecoraro V L, Baldwin M J and Gelasco A 1994 Chem. Rev. 94 807; (b) Dismukes G C 1996 Chem. Rev. 962909

4. Burger R M 2000 Struct. Bond. 97287

5. Karlsson A, Parales J V, Parales R E, Gibson D T, Eklund H and Ramaswamy S 2003 Science 2991039

6. (a) Ortiz de Montellano P R Cytochrome P450: Structure, Mechanism, and Biochemistry, 3rd ed. New York: Kluwer 2005; (b) Abu-Omar M M, Loaiza A and Hontzeas N 2005 Chem. Rev. 105 2227; (c) Krebs C, Fujimori D G, Walsh C T and Bollinger Jr. J M 2007 
Acc. Chem. Res. 40 484; (d) Green M T 2009 Curr. Opin. Chem. Biol. 1384 (e) Ortiz de Montellano P R 2010 Chem. Rev. 110 932; (f) Shaik S, Lai W, Chen H and Wang Y. 2010 Acc. Chem. Res. 431154

7. (a) Lee D and Lippard S J In Comprehensive Coordination Chemistry II; From Biology to Nanotechnology; Vol. 8, p 309 Oxford: Elsevier Ltd. 2004; (b) Du Bois J, Mizoguchi T J and Lippard S J 2000 Coord. Chem. Rev. 200-202 443; (c) Kurtz Jr. D M 1990 Chem. Rev. 90 585

8. (a) Makhlynets O V, Das P, Taktak P, Flook M, Mas-Ballesteì R, Rybak-Akimova E V, Que Jr. L 2009 Chem. Eur. J. 15 13171; (b) Makhlynets O V and RybakAkimova E V 2010 Chem. Eur. J. 16 13995; (c) Chen K, Costas M and Que Jr. L 2002 J. Chem. Soc. Dalton Trans. 672: (d) Park M J, Lee J, Suh Y, Kim J and Nam W 2006 J. Am. Chem. Soc. 1282630

9. (a) MacBeth C E, Golombek A P, Young V G Jr, Yang C, Kuczera K, Hendrich M P and Borovik, A S 2000 Science 289 938; (b) Lacy D C, Gupta R, Stone K L, Greaves J, Ziller J W, Hendrich M P and Borovik A S 2010 J. Am. Chem. Soc. 132 12188; (c) Shook R L and Borovik A S 2008 Chem. Commun. 6095

10. (a) Rohde J-U, In J-H, Lim M H, Brennessel W W, Bukowski M R, Stubna A, Münck E, Nam W and Que Jr. L 2003 Science 299 1037; (b) de Oliveira F T, Chanda A, Banerjee D, Shan X, Mondal S, Que Jr. L, Bominaar E L, Münck E and Collins T J 2007 Science 315 835; (c) Lyakin O Y, Bryliakov K P, Britovsek G J P and Talsi E P 2009 J. Am. Chem. Soc. 13110798

11. (a) Srinvasan K, Michaud P and Kochi J K 1986 J. Am. Chem. Soc. 108 2309; (b) Zhang W, Loebach J L, Wilson S R and Jacobsen R N 1990 J. Am. Chem. Soc. 112 2801; (c) Paluki M, Finney N S, Pospisil P J, Guler M L, Ishida T and Jacobsen E N 1998 J. Am. Chem. Soc. 120 948

12. (a) Metallo-porphyrins in catalytic oxidations, ed. Sheldon R A Ed.; M. New York: Dekker 1994; (b) Nam W and Valentine J S 1993 J. Am. Chem. Soc. 115 1772; (c) Groves J T, Lee J and Marla S S 1997 J. Am. Chem. Soc. 119 6269; (d) Jin N and Groves J T 1999 J. Am. Chem. Soc. 121 2923; (e) Jaccob M, Ansari A, Pandey B and Rajaraman G 2013 Dalton Trans. (doi: 10.1039/C3DT52290C)

13. (a) Shirin Z, Hammes B S, Young Jr. V G and A S Borovik 2000 J. Am. Chem. Soc. 122 1836; (b) Gupta R, MacBeth C E, Young V G, Jr. and Borovik A S 2002 J. Am. Chem. Soc. 124 7; (c) Gupta R and Brovik A S 2003 J. Am. Chem. Soc. 12513234

14. Parsell T H, Behan R K, Green M T, Hendrich M P and Borovik A S 2006 J. Am. Chem. Soc. 1288728

15. (a) Shook R L, Gunderson W A, Greaves J, Ziller J W, Hendrich M P and Borovik A S 2008 J. Am. Chem. Soc. 130 8888; (b) Shook R L, Peterson S M, Greaves J, Moore C, Rheingold A L and Borovik, A S $2011 \mathrm{~J}$. Am. Chem. Soc. 1335810

16. (a) Ansari A, Kaushik A and Rajaraman G 2013 J. Am. Chem. Soc. 135 4235; (b) Jaccob M and Rajaraman G 2012 Dalton Trans. 41 10430; (c) Dey A and Ghosh A 2002 J. Am. Chem. Soc. 1243206 (d) Bassan A, Blomberg M R A, Siegbahn P E M and Que Jr. L 2002 J. Am. Chem. Soc. 12411056
17. MacBeth C E, Gupta R, Mitchell-Koch K R, Young Jr. V G, Lushington G H, Thompson W H, Hendrich M P and Borovik A S 2004 J. Am. Chem. Soc. 126 2556

18. (a) Seo M S, Kim N H, Cho K-B, So J E, Park S K, Clemancey M, Garcia-Serres R, Latour J-M, Shaik S and Nam W 2011 Chem. Sci. 2 1039; (b) Isabella H-K, Mück-Lichtenfeld C and Grimme S 2009 Croat. Chem. Acta 82 115; (c) Lim M H, Rohde J-U, Stubna A, Bukowski M R, Costas M, Ho R Y N, Münck E, Nam W and Que L Jr 2003 Proc. Natl. Acad. Sci. U.S.A. 100 3665; (d) Rohde J-U, Stubna A, Bominaar E L, Münck E, Nam W and Que Jr. L 2006 Inorg. Chem. 45 6435

19. (a) Bassan A, Blomberg M R A, Siegbahn P E M and Que Jr. L 2005 Chem. Eur. J. 11 692; (b) Bassan A, Blomberg M R A and Siegbahn P E M 2003 Chem. Eur. J. 94055

20. (a) Parsell T H, Yang M-Y and Brovik A S 2009 J. Am. Chem. Soc. 131 2762; (b) Gupta R, MacBeth C E, Young V G and Borovik A S 2002 J. Am. Chem. Soc. 124 1136

21. Gupta R, Taguchi T, Borovik A S and Hendrich M P 2013 Inorg. Chem. 5212568

22. Gaussian 09, Revision A.1, Frisch M J, Trucks G W, Schlegel H B, Scuseria G E, Robb M A, Cheeseman J R, Scalmani G, Barone V, Mennucci B, Petersson G A, Nakatsuji H, Caricato M, Li X, Hratchian H P, Izmaylov, A F, Bloino J, Zheng G, Sonnenberg J L, Hada M, Ehara M Toyota K, Fukuda R, Hasegawa J, Ishida M, Nakajima T, Honda, Y, Kitao O, Nakai H, Vreven T, Montgomery Jr. J A, Peralta J E, Ogliaro F, Bearpark M, Heyd J J, Brothers E, Kudin K N, Staroverov V N, Kobayashi R, Normand J, Raghavachari K, Rendell A, Burant J C, Iyengar S S, Tomasi J, Cossi M, Rega N, Millam J M, Klene M, Knox J E, Cross J B, Bakken V, Adamo C, Jaramillo J, Gomperts R, Stratmann R E, Yazyev O, Austin A J, Cammi R, Pomelli C, Ochterski J W, Martin R L, Morokuma K, Zakrzewski V G, Voth G A, Salvador P, Dannenberg J, Dapprich S, Daniels A D, Farkas Ö, Foresman J B, Ortiz J V, Cioslowski J and Fox D J, Gaussian, Inc. Wallingford CT 2009

23. Grimme, S J 2006 Comput. Chem. 271787

24. (a) Dunning T H, Jr., Hay P J In Modern theoretical chemistry, ed. Schaefer, H F, III, New York: Plenum 1976 Vol. 3, p 1; (b) Hay P J and Wadt W R 1985 J. Chem. Phys. 82270 (c) Wadt W R and Hay P J 1985 J. Chem. Phys. 82 284; (d) Hay P J and Wadt W R 1985 J. Chem. Phys. 82299

25. Ditchfield R, Hehre W J and Pople J A 1971 J. Chem. Phys. 54724

26. (a) Schäfer A, Horn H and Ahlrichs R 1992 J. Chem. Phys. 97 2571; (b) Schäfer C, Huber C and Ahlrichs R 1994 J. Chem. Phys. 1005829

27. (a) Fluckiger P, Luthi H P, Portmann S and Weber J Molekel 4.3 Swiss Center for Scientific Computing: Manno, Switzerland, 2000; (b) Portmann S and Lüthi, H P 2000 Chimia. 54766

28. Mennucci B 2012 Comput Mol Sci. 2386

29. Feig A L and Lippard S J 1994 Chem. Rev. 94759 
30. (a) Ye S and Neese F 2011 Proc. Natl. Acad. Sci. USA 108 1228; (b) de Visser S P, Rohdeb R-U, Lee Y-M, Cho J and Nam W 2013 Coord. Chem. Rev. 257381

31. (a) Nishida Y, Morimoto Y, Lee, Y-M, Nam W and Fukuzumi S 2013 Inorg. Chem. 52 3094; (b) Wang D, Zhang Mo, Buhlmann P and Que Jr. L $2010 \mathrm{~J}$. Am. Chem. Soc. 1327638
32. (a) de Visser S P, Oh K, Han A-R and Nam W 2007 Inorg. Chem. 46 4632; (b) Olsson E, Mertinez A, Teigen K and Jensen V R 2011 Eur. J. Inorg. Chem. 2720

33. Taguchi T, Gupta R, Lassalle-Kaiser B, Boyce D W, Yachandra V K, Tolman W B, Yano J, Hendrich M P and Borovik A S 2012 J. Am. Chem. Soc. 1341996 